\title{
Recombinant Gonadorelin
}

National Cancer Institute

\section{Source}

National Cancer Institute. Recombinant Gonadorelin. NCI Thesaurus. Code C613.

A synthetic luteinizing hormone releasing hormone $(\mathrm{LHRH})$ identical to or similar to the endogenous hormone. Synthesized in and secreted by the hypothalamus, gonadorelin binds to transmembrane LHRH receptors on pituitary gonadotrophic cells, thereby stimulating synthesis and secretion of gonadotropins. Continuous administration of gonadorelin desensitizes the gonadotrophic cells, a negative feedback effect. This agent can be used in treatment of hypothalamic amenorrhea and evaluation of hypothalamic/pituitary function. 